\title{
First-trimester uterine artery Doppler: does it matter if the bladder is full or empty?
}

\author{
Ayşegül Özel (iD), Cihat Şen \\ Perinatology Clinic, Department of Gynecology and Obstetrics, Cerrabpaşa Faculty of Medicine, İstanbul University-Cerrahpaşa, Istanbul, Turkey
}

\begin{abstract}
Objective: We aimed to investigate the impacts of the bladder fullness on the parameters of first-trimester uterine artery Doppler.

Methods: Fifty-one pregnant women, who admitted to our clinic for the first-trimester aneuploidy screening, participated in this prospective study. Bilateral uterine artery Doppler parameters were first measured when the bladder was full. The second measurement was carried out by the same clinician right after the bladder was emptied.

Results: The mean weeks of gestation of the patients were $12.5 \pm 0.7$. With the full bladder, the mean uterine artery pulsatility index (UtA PI) was $1.80 \pm 0.65$ on both right and left sides. In the measurements carried out when the bladder was empty, UtA PI was $1.77 \pm 0.58$ on the left side and $1.71 \pm 0.59$ on the right side $(\mathrm{p}=0.512$ and $\mathrm{p}=0.503$, respectively).

Conclusion: Bladder being full when performing preeclampsia screening during first-trimester aneuploidy screening does not affect the parameters of uterine artery Doppler.
\end{abstract}

Keywords: Bladder volume, first-trimester screening, uterine artery Doppler.

\section{Introduction}

The numbers of the studies for the prediction of various conditions in the first trimester such as preeclampsia and fetal growth restriction associated with the poor gestational outcomes have increased rapidly as the firsttrimester aneuploidy screening has become a standard part of the gestational follow-up. It is considered that the underlying pathology of both preeclampsia and fetal

\section{Özet: Ilk trimester uterin arter Doppleri: Mesanenin dolu ya da boş olması fark eder mi?}

Amaç: İlk trimester taramasında mesanenin dolu olma durumunun uterin arter Doppler parametrelerine etkisini araştırmayı amaçladık.

Yöntem: Prospektif olarak dizayn edilmiş bu çalışmaya kliniğimize ilk trimester anöploidi taraması için başvuran 51 gebe katıldı. Bilateral uterin arter Doppler değişkenleri ilk olarak mesane dolu iken ölçüldü. İkinci ölçüm ise mesanenin hemen boşaltılmasını takiben aynı klinisyen tarafindan yapıldı.

Bulgular: Hastaların ortalama gebelik haftası $12.5 \pm 0.7$ olarak bulundu. Dolu mesane ile birlikte ortalama uterin arter pulsatilite indeksi (UtA PI), sağ ve sol her iki tarafta da $1.80 \pm 0.65$ olarak bulundu. Boş mesane ile birlikte yapılan ölçümde ortalama UtA PI sol tarafta $1.77 \pm 0.58$, sağ tarafta $1.71 \pm 0.59$ olarak bulundu (sirasıly $\mathrm{p}=0.512$ ve $\mathrm{p}=0.503)$.

Sonuç: İlk trimesterde anöploidi taraması sırasında preeklampsi taraması yaparken mesanenin dolu olması uterin arter Doppler değişkenlerini etkilememektedir.

Anahtar sözcükler: Mesane hacmi, ilk trimester tarama, uterin arter Doppleri.

growth restriction is the insufficient trophoblastic invasion of the myometrial part of the spiral arteries. ${ }^{[1,2]}$ There are studies in the literature investigating the uterine artery Doppler for the prediction of early-onset preeclampsia. ${ }^{[3-5]}$ However, there is limited number of studies investigating the factors affecting uterine artery flow. ${ }^{[6,7]}$ In the studies describing the accurate and proper measurement technique, no opinion was expressed

Correspondence: Ayşegül Özel, MD. Perinatology Clinic, Department of Gynecology and Obstetrics, Cerrahpaşa Faculty of Medicine, Istanbul University-Cerrahpaşa, Fatih, Istanbul, Turkey. e-mail: ozelaysegul@hotmail.com / Received: October 4, 2019; Accepted: October 21, 2019 Please cite this article as: Özel A, Şen C. First-trimester uterine artery Doppler: does it matter if the bladder is full or empty? Perinatal Journal 2019;27(3):125-129. doi:10.2399/prn.19.0273001 
about bladder whether it should be full or empty. ${ }^{[8,9]}$ Full bladder may lead to the increase in Doppler indices associated with the stretch in uterine arteries. There are two studies in the literature performed on pregnant and nonpregnant women which investigate the impact of bladder fullness on the indices of uterine artery Doppler. ${ }^{[10,11]} \mathrm{In}$ our study, we aimed to investigate the impacts of the bladder fullness on the parameters of uterine artery Doppler in pregnant women.

\section{Methods}

Fifty-one pregnant women, who admitted to our clinic in 2017 for the first-trimester aneuploidy screening, participated in our study. The pregnant women with hypertension, diabetes or vasculopathy, multiple pregnancies and pregnant women who were on anticoagulant medication were excluded from the study. The approval of ethics committee for this prospective study was obtained from the Ethics Committee of Cerrahpaşa Faculty of Medicine with the approval number 04/10/2017-368029. Informed consents of all participants were obtained before the study and the principles of the declaration of Helsinki were followed. All ultrasound examinations were performed by the same clinician using Voluson Expert 10 (GE Healthcare Technologies, Chicago, IL, USA) with 2.08.0 MHz transabdominal probe. While the first measurement for bilateral uterine artery Doppler parameters was carried out when the patients were in need to urinate (with full bladder), the second measurement was carried out right after the patients urinated. Uterine artery Doppler measurement was carried out by imaging both sides of uterine arteries through color Doppler function by obtaining the image of the transabdominal midsagittal cervical canal and moving the probe towards the right and left sides slowly. When performing pulsed Doppler, the sample interval was set to $2 \mathrm{~mm}$ where the angle of insonation was less than $30^{\circ}$ and at least 3 consecutive wavelengths were recorded (Figs. 1a and b).

When the bladder was full, the maximal width, length, and anterior-posterior (height) diameters were measured transabdominally. The formula of length $x$ width $\mathrm{x}$ height $\mathrm{x} 0.52$ was used to calculate the bladder volume $^{[12]}$ (Figs. 2a and b).

SPSS 20.0 package software (SPSS Inc., Chicago, IL, USA) was used for statistical analysis. The conformation of parameters to the normal distribution was analyzed by Kolmogorov-Smirnov test. Due to the conformation of parameters to the normal distribution, paired $t$ test was used for the comparison of the measurements carried out when bladder was full and empty. $\mathrm{McNemar}$ test was used to compare notches in the uterine arteries. A p-value $<0.05$ was considered statistically significant.

\section{Results}

The clinical characteristics of the cases are shown in the Table 1. The mean weeks of gestation of the patients
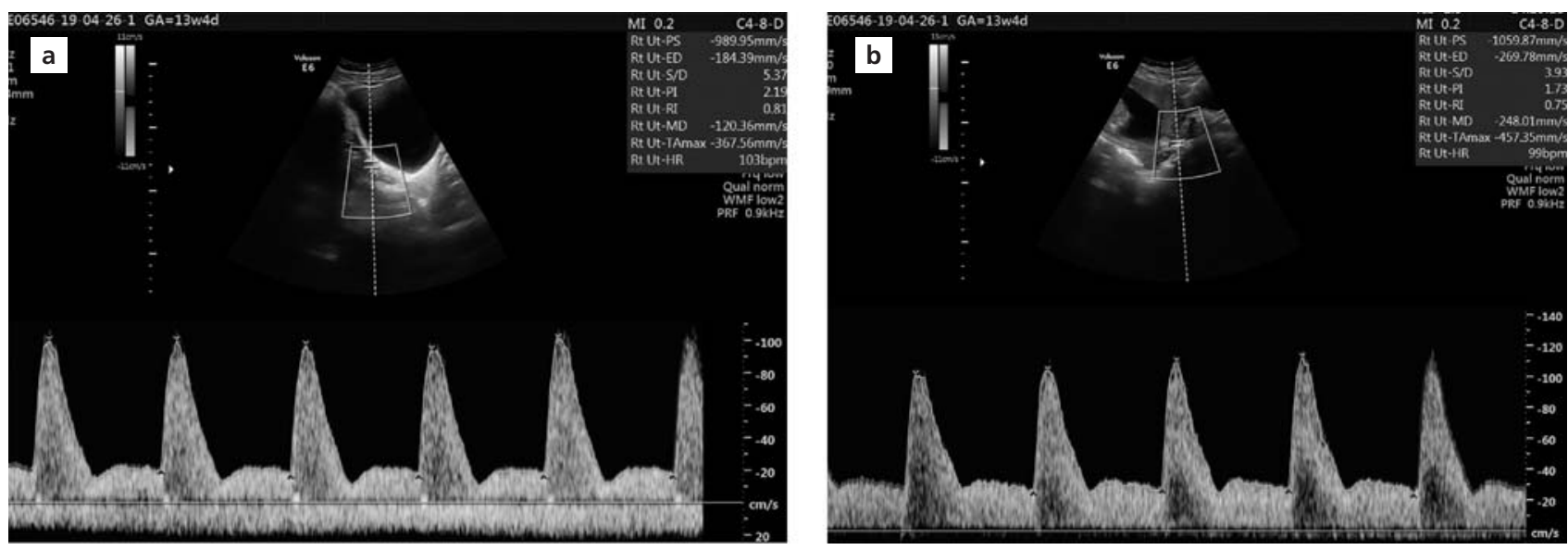

Fig. 1. Right uterine artery Doppler measurements with (a) full and (b) empty bladder. 

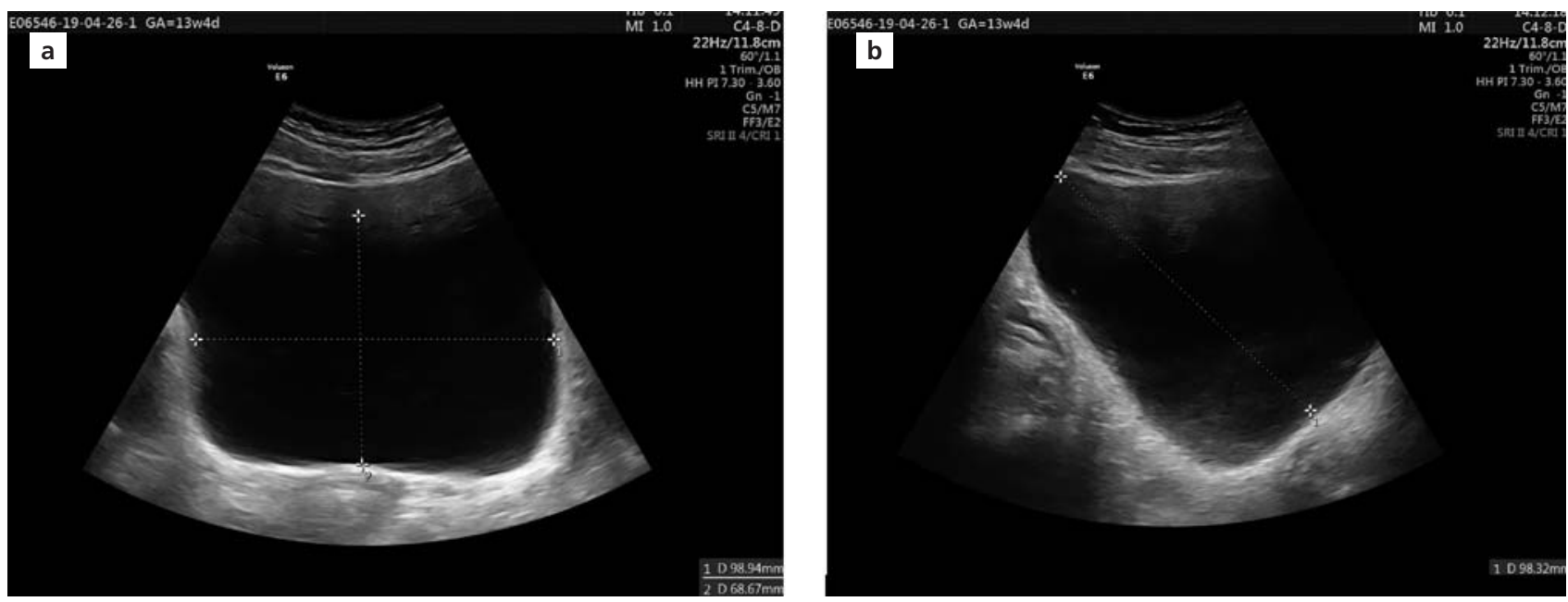

Fig. 2. (a, b) Measurements of bladder volume.

were $12.5 \pm 0.7$. Mean left and right UtA PI measured with full bladder was $1.80 \pm 0.65$. Mean UtA PI measured with empty bladder was $1.77 \pm 0.58$ on the left side and $1.71 \pm 0.59$ on the right side. There was no statistically significant difference between the measurements with full and empty bladders for the left and right sides $(\mathrm{p}=0.512$ and $\mathrm{p}=0.503$, respectively). Similarly, there was no statistically significant difference in the mean uterine artery resistance indices on the left and right sides $(\mathrm{p}=0.562$ and $\mathrm{p}=0.713$, respectively) (Table 2 and Figs. $3 \mathbf{a}$ and $\mathbf{b})$. No difference was found in terms of the early diastolic notch presence when bladder was full or empty (left side $\mathrm{p}=0.180$, right side $\mathrm{p}=1.00$ ). The mean volume of the full bladder was $247.3 \pm 19.1 \mathrm{ml}$. The length of cervix was measured longer in a statistically significant way when the bladder was full $(40.3 \pm 6.9 \mathrm{~mm}$ when the bladder was full, $34.7 \pm 3.8 \mathrm{~mm}$ when the bladder was empty, $\mathrm{p}=0.000$ ).

\section{Discussion}

Uterine artery Doppler flow may be affected by the hormonal changes in the menstrual cycle, maternal heart rate, blood pressure and various medications. ${ }^{[13]}$ In our study, we investigated if bladder being full or empty has any impact on the first-trimester uterine artery Doppler measurement. We showed that full bladder did not change uterine artery Doppler indices.

In recent years, the number of the studies, in which the first-trimester uterine artery Doppler measure-
Table 1. The clinical data of the patients $(n=51)$.

\begin{tabular}{lc}
\hline Age (year) (mean \pm standard deviation) & $30.3 \pm 5.6$ \\
BMI $\left(\mathrm{kg} / \mathrm{m}^{2}\right)($ mean \pm standard deviation) & $23.9 \pm 4.2$ \\
Week of gestation (mean \pm standard deviation) & $12.5 \pm 0.7$ \\
Nulliparity $(\mathrm{n}, \%)$ & $18,35.3$ \\
Smoking $(\mathrm{n}, \%)$ & $2,3.9$ \\
Pregnancy by ART $(\mathrm{n}, \%)$ & $4,7.8$ \\
\hline
\end{tabular}

ART: Assisted reproduction techniques; BMI: Body mass index.

ments may predict the quality and quantity of uterine artery flow in the following phases of pregnancy and can be used in the prediction of associated pregnancies with high risk, has increased. Uterine artery Doppler examination can easily be performed transabdominally during first-trimester aneuploidy screening. Bladder

Table 2. The comparison of the measurements performed with ful and empty bladders.

\begin{tabular}{lccc} 
& $\begin{array}{c}\text { Full bladder } \\
\text { (mean } \pm \text { standard } \\
\text { deviation) }\end{array}$ & $\begin{array}{c}\text { Empty bladder } \\
\text { (mean } \pm \text { standard } \\
\text { deviation) }\end{array}$ & p-value \\
Left UtA PI & $1.80 \pm 0.65$ & $1.77 \pm 0.58$ & 0.512 \\
Left UtA RI & $0.76 \pm 0.10$ & $0.75 \pm 0.10$ & 0.562 \\
Right UtA PI & $1.80 \pm 0.65$ & $1.71 \pm 0.59$ & 0.503 \\
Right UtA RI & $0.75 \pm 0.12$ & $0.74 \pm 0.11$ & 0.713 \\
Cervix length & $40.3 \pm 6.9$ & $34.7 \pm 3.8$ & 0.000 \\
\hline
\end{tabular}

RI: Resistance index; UtA PI: Uterine artery pulsatility index. 

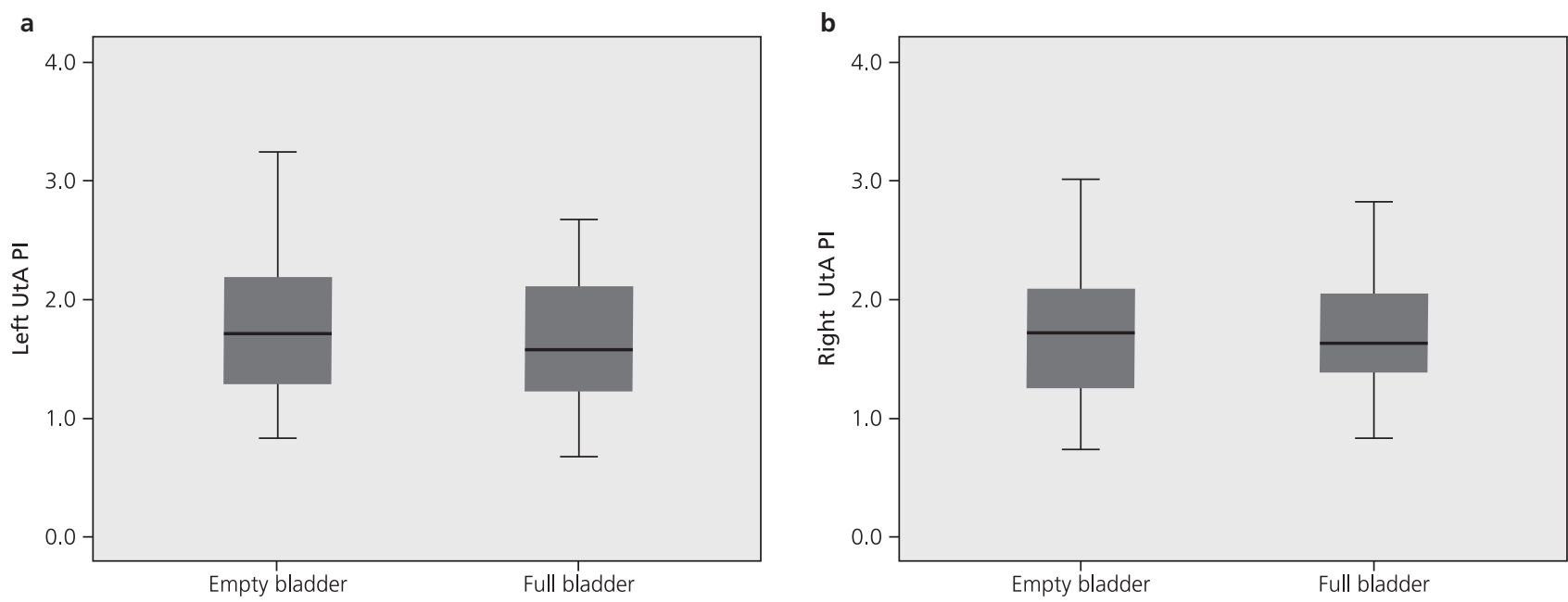

Fig. 3. Box plot graphs of the measurements of (a) left and (b) right uterine artery pulsatility indices with empty and full bladders ( $p=0.512$ and $p=0.503$, respectively).

being full during nuchal translucency measurement may sometimes increase the imaging quality by decreasing the negative factors related to patients. We can say that it is unnecessary to ask patients with full bladders to empty their bladders for the uterine artery Doppler measurement to be performed during this examination.

Serevalli et al. ${ }^{[10]}$ conducted a study on 45 pregnant women and they reported that they did not find any significant difference in the comparison of uterine artery Doppler measurements when bladder was full and empty. In their study conducted on 39 non-pregnant women, Battaglia et al. ${ }^{[1]]}$ found significantly high Doppler indices when their bladders were full. They explained this result with the fact that the reactions associated with the sympathetic innervations increasing during bladder filling affect the sympathetic nerve vasoconstriction in the periarterial region of uterine arteries. We can attribute this difference in the results of two populations, which comprised of pregnant and non-pregnant women, to the reconstruction of musculo-elastic structure of uterine artery wall by trophoblastic invasion during pregnancy. ${ }^{[14]}$ Further studies to investigate how full bladder affects uterine artery Doppler parameters may be planned for the cases where insufficient trophoblastic invasion in the vessel wall is held responsible for its pathology.

\section{Conclusion}

The full bladder has no significant impact on Doppler parameters in the uterine artery Doppler screening performed for the prediction of preeclampsia during first-trimester aneuploidy screening. If the measurement of cervix length will not be a part of this examination, we may not ask patients to empty their bladders before Doppler measurement. Low number of patients and the lack of equal fullness volume of bladders in all patients are among the limitations of this study.

Conflicts of Interest: No conflicts declared.

\section{References}

1. Wallace AE, Host AJ, Whitley GS, Cartwright JE. Decidual natural killer cell interactions with with trophoblasts are impaired in pregnancies at increased risk of preeclampsia. Am J Pathol 2013;183:1853-61.

2. Wallace AE, Whitley GS, Thilaganathan B, Cartwright JE. Decidual natural killer cell receptor expression is altered in pregnancies with impaired vascular remodeling and a higher risk of pre-eclampsia. J Leukoc Biol 2015;97:79-86.

3. Poon LC, Staboulidou NM, Maiz N, Plasencia W, Nicolaides $\mathrm{KH}$. Hypertensive disorders in pregnancy: screening by uterine artery Doppler at 11-13 weeks. Ultrasound Obstet Gynecol 2009;34:142-8.

4. Odibo AO, Zhong Y, Goetzinger KR, Odibo L, Bick JL, Bower CR, et al. First-trimester placental protein 13, PAPPA, uterine artery Doppler and maternal characteristics in the prediction of pre-eclampsia. Placenta 2011;32:598-602. 
5. Poon LC, Karagiannis G, Leal A, Romero XC, Nicolaides $\mathrm{KH}$. Hypertensive disorders in pregnancy: screening by uterine artery Doppler imaging and blood pressure at 11-13 weeks. Ultrasound Obstet Gynecol 2009;34:497-502.

6. Prefumo F, Bhide A, Sairam S, Penna L, Hollis B, Thilaganathan B. Effect of parity on second-trimester uterine artery Doppler flow velocity and waveforms. Ultrasound Obstet Gynecol 2004;23:46-9.

7. Pirhonen J, Bergersen TK, Abdlenoor M, Dubiel M, Gudmundsson S. Effect of maternal age on uterine flow impedance. J Clin Ultrasound 2005;33:14-7.

8. Khalil A, Nicolaides KH. How to record uterine artery Doppler in the first trimester. Ultrasound Obstet Gynecol 2013;42: 478-9.

9. Plasencia W, Maiz N, Bonino S, Kaihura C, Nicolaides KH. Uterine artery Doppler at $11+0$ to $13+6$ weeks in the prediction of preeclampsia. Ultrasound Obstet Gynecol 2007;30: $742-9$.
10. Serevalli V, Masini G, Morelli C, Di Tomasso M, Pasquini L, Petraglia F. Impact of bladder filling on uterine artery Doppler variables in the first trimester of pregnancy. J Clin Ultrasound 2019;47:83-7.

11. Battaglia C, Artini PG, D’Ambrogio G, Galli P, Genazzani A. Uterine and ovarian blood flow measurement. Does the full bladder modify the flow resistance? Acta Obstet Gynecol Scand 1994;73:716-8.

12. Ballstaedt L, Woodbury B. Bladder Post Void Residual Volume. [Updated 2019 Mar 31]. In: StatPearls [Internet]. Treasure Island (FL): StatPearls Publishing; 2019 Jan. Available from: https://www.ncbi.nlm.nih.gov/books/NBK539839/

13. Khong SL, Kane SC, Brennecke SP, da Silva Costa F. Firsttrimester uterine artery Doppler analysis in the prediction of later pregnancy complications. Dis Markers 2015;2015: 679730.

14. Brosens I, Brosens JJ, Muter J, Puttemans P, Benagiano G. Preeclampsia: the role of persistent endothelial cells in uteroplacental arteries. Am J Obstet Gynecol 2019;221:219-26.

Bu makalenin kullanım izni Creative Commons Attribution-NoCommercial-NoDerivs 3.0 Unported (CC BY-NC-ND3.0) lisansı aracılığıyla bedelsiz sunulmaktadır. / This work is licensed under the Creative Commons Attribution-NonCommercial-NoDerivs 3.0 Unported (CC BY-NC-ND3.0) License. To view a copy of this license, visit http://creativecommons.org/licenses/by-nc-nd/3.0/ or send a letter to Creative Commons, PO Box 1866 , Mountain View, CA 94042, USA. 